\title{
O destino de Jerusalém nas negociações israelo-palestinas
}

\author{
CARMEN LÍCIA PALAZZO DE ALMEIDA
}

Cidade sagrada para os três grandes grupos religiosos monoteístas cristão, muçulmano e judeu - Jerusalém carrega o peso das lutas registradas na memória de uma boa parte da humanidade há quase três mil anos. Saques, destruição, cobiça e intransigência têm marcado a história desta pequena área de deserto, semeada de pedras, inóspita e no entanto disputada com ardor por civilizações que, em algum momento, ambicionaram a hegemonia regional ou ali buscaram refúgio contra as perseguições e os massacres.

Atualmente Jerusalém constitui um dos problemas mais sérios a serem resolvidos quando o processo de paz no Oriente Médio já estiver mais adiantado. Reivindicada como capital histórica por judeus e palestinos, concentra em seu pequeno espaço uma população dividida e ciosa de suas raízes na região.

Os hebreus, originariamente tribos nômades que, por motivos historicamente não conhecidos, engajaram-se a serviço dos faraós, deixaram definitivamente o Egito entre 1279 e 1209 antes de Cristo, retornando então em diversas levas e épocas diferentes ao deserto. Este retorno passou a ser transmitido pela memória judaica como a história de um êxodo único, organizado por Moisés. Em torno de 1030 a.C., as diversas tribos de hebreus já se encontravam sedentarizadas na "Terra de Israel” e até 931 a.C., os reis Saul, depois Davi e Salomão, governaram um reino unificado, dividido após a morte de Salomão em reino de Judá e de Israel. Com a tomada de Samaria pelos assírios, em 722 a.C. e de Jerusalém, em 587 a.C., chegava ao final o primeiro Estado hebreu, que viria a ser constantemente resgatado na evocação da Terra Prometida.

Seguiram-se o exílio dos judeus na Babilônia, a expansão persa, o novo retorno dos hebreus e o estabelecimento de uma nação na Judéia, tendo como centro principal justamente a cidade de Jerusalém. Ocorreram outros domínios, invasões, destruições, numa região onde o solo pedregoso, o tamanho do deserto e sobretudo a exigüidade das terras aptas à sobrevivência serão parte importante num estado de luta quase permanente. De 63 a.C. até o ano 313 da era cristã a hegemonia foi romana. De 313 a 636 o Império Bizantino expandiu-se até as terras que os romanos haviam denominado Palestina e, cinco anos após a morte de Maomé, os muçulmanos conquistaram Jerusalém, no início de 637. Os Cruzados, cristãos latinos, invadiram-na em 1099, massacrando muçulmanos e judeus e, em 1187, Saladino a recupera. A dinastia otomana, iniciada em 1517, construiu as muralhas que permanecem até hoje. Em 11 de dezembro de 1917, os turcos entregaram Jerusalém ao general inglês Edmund Allenby. Seguiu-se, após a Segunda Guerra, a criação do Estado de Israel e o início do conflito de partilha do território que, após 
muitos percalços, chegou a um ponto no qual existe ao menos a possibilidade de se encontrar uma solução negociada.

O enfoque cronológico é importante para situar o impressionante cruzamento de culturas em tão exíguo território, levando a um estado de conflitos latentes que datam não de séculos, mas de milênios.

Embora a atual disputa pela hegemonia regional seja entre judeus e palestinos, a cidade de Jerusalém é geograficamente dividida em pelo menos quatro comunidades principais, possuindo bairros muçulmano, armênio, judaico e cristão de predominância latina. A exclusão não é, portanto, apenas religiosa, mas se reveste de caráter nacionalista, com raízes em inúmeros contenciosos não resolvidos no passado. Constantes rixas e afrontamentos mais sérios já envolveram os distintos grupos cristãos que compartilham o Santo Sepulcro, especialmente os coptas, sírios, armênios, gregos e latinos.

O peso da intolerância é muito claro neste pedaço de terra onde os particularismos se afrontam a cada momento e onde o dia-a-dia gira em torno de duas forças dificilmente redutíveis a comportamentos racionais: a fé e o nacionalismo.

Neste quadro explosivo coloca-se um problema político a ser resolvido em breve: o destino de Jerusalém quando a paz no Oriente Médio já estiver em vias de ser estabelecida. O grupo cristão politicamente ativo tem procurado evitar a conotação religiosa em sua militância pelos direitos palestinos e atua vinculado à OLP, que assume uma posição bastante pragmática. Entre os judeus há os que preferem descartar o caráter místico e mítico de Jerusalém em função de uma negociação viável a curto prazo. Mas há também os que passaram à ofensiva, como é o caso do atual governo, que incentiva as novas construções de modo que, no momento de uma decisão sobre a eventual partilha territorial, não haja dúvidas quanto ao maior peso numérico dos judeus.

Alguns projetos específicos, no entanto, já demonstraram que o pragmatismo pode render bons frutos para o conjunto da população. Recentemente foi levantada a possibilidade de investimentos na área de turismo, com uma colaboração tripartite de Israel, dos palestinos e da Jordânia, visando o desenvolvimento da região do Mar Morto.

Jerusalém permanece, porém, como um enigma cuja solução ainda não foi encontrada. A internacionalização da cidade, proposta pela ONU em 1947 e endossada pelo próprio Ben Gurion, não chegou a se concretizar em virtude do estado de guerra quase permanente após a independência de Israel. Atualmente é pouco provável que seja efetivamente adotada, pois implicaria no engajamento de outros países em um momento difícil para as relações internacionais. No entanto, a partilha pura e simples está longe de ser aceita por ambas as partes.

O caminho mais razoável parece ser o que conduz a uma laicização do problema. Enquanto a discussão sobre o destino de Jerusalém se revestir de um caráter religioso, buscando raízes históricas para justificar comportamentos fundamentalistas tanto do lado palestino quanto do judeu, certamente não se encontrará uma solução definitiva. 